\title{
Development of a conceptual model of multi-skilled specialist training
}

\author{
Mammadov, Javanshir ${ }^{\text {; }}$ Talibov, Natig ${ }^{b}$; Huseynov, Agil ${ }^{c}:$ Abdullayev, Loghman ${ }^{d}$ and \\ Mammadova, Samira ${ }^{\mathrm{e}}$ \\ ${ }^{\mathrm{a}}$ Chair of Process automation, Sumqayit State University, Azerbaijan, ${ }^{\mathrm{b}}$ Vice-rector on \\ Learning and Teaching technologies, Sumgayit State University, Azerbaijan, ${ }^{\mathrm{c}}$ Chair of \\ Information Technology and Programming, Sumgait State University, Azerbaijan, ${ }^{\mathrm{d}}$ Chair of \\ Finance and Accounting, Sumgayit State University, Azerbaijan, ${ }^{\mathrm{e}}$ Department of \\ International Cooperation, Sumgait State University, Azerbaijan
}

\begin{abstract}
In order to develop the higher education system of Azerbaijan, training of highly skilled specialists using the innovative methods in teaching process and scientific research had been disscused at Sumgayit State University. The conceptual model of the process of preparation of highly qualified (multy) specialists was proposed on the basis of chairs in engineering and economics faculties of Sumgayit State University.

Priority specialties and scientific directions of the departments of Engineering and Economics of Sumgayit State University were determined and the functional scheme of complex educational training - scientific research - production - commissioning system was proposed based on the principles of flexible production. An activity block diagram for the development of an innovative project in training, scientific research, production and commercial system has been developed.
\end{abstract}

Keywords: Multi-specialty; conceptual model; innovation; scientific research; flexible manufacturing. 


\section{Introduction}

One of the special areas of the Republic of Azerbaijan in modern period is the education system. In the recent decisions made by the President of the Republic of Azerbaijan was based on development of the education system, application of new innovative methods and projects in higher education institutions, the professors and students (directions of the reforms had been determined due to the Decree of the President of the Republic of Azerbaijan dated May 22, 2009, No. 295) improvement of the social situation of the teaching staff and the promotion of higher education in Azerbaijan to the international level. In this sense, the creation of a flexible scientific - research - production system in the framework of the introduction of new innovative science and education principles, technologies in higher education schools is one of the urgent issues of the modern era.

In Sumgayit, the industrial city of the Republic of Azerbaijan, scientific-research institutes, higher education institutions, technological parks and industrial enterprises function individually. However, the analysis of existing world scientific research and technological processes shows that their work is carried out in a complex form: educational and scientific research - production - business scheme [Prencipe A.].

\section{Justification of preparation of multidisciplinary qualified specialists in the higher education system}

The level of training of graduates of Azerbaijani higher education institutions in engineering or economics does not allow them to be admitted directly into large enterprises. Due to the fact that high requirements in the workplace, engineering and economically less practical experience do not allow working as a professional specialist in direct production. So, Sumgait State University (SSU) focuses to the preparation of multidisciplinary specialist in a complex teaching-learning, scientific-research and flexible production system.

As a result of the global application of new information technologies and computer techniques in the 21 st century, medical informatics, bioinformatics, and so on scientific directions have been formed. Some scientific directions have been formed. New innovative and scientific specialties are taught in the modern education system. Automation and intellectual management of technological processes in the chemical, metallurgical, automotive and mechanical engineering industries, automation of economic issues; the opportunities for automatic control and management of environmental processes have been expanded. In higher education schools, including SSU, scientific research and studies of physics, mathematics, energetics, chemistry, medicine, biology, geology, ecology, and others are carried out by the synthesis of new information technologies and computer technology [Lamperti, F.]. 
In order to continually increase the country's economic potential and to be competitive in the international area, it is desirable to prepare specialists who know the principles of modern finance, accounting and business in various fields of application [Dezilacruz, M.].

It is important to create a new training and training center, specialized research laboratories, flexible production areas and economic management division for economically stimulation and preparation of professional specialists due to the mentioned specialities. these principles are based on the issue of developing a conceptual model of preparing specialists who can use theoretical and practical skills in the teaching process of computer science and economics management.

The purpose of the thesis is to develop a conceptual model of multidisciplinary training of specialists with the help of complex learning and training, modern research and testing laboratories, flexible production area and commercial center on the basis of Chairs operating in the Faculties of "Engineering" and "Economics" at SSU.

\section{Development of SDU educational curriculum - scientific research - production - operating system functional scheme}

To achieve this goal, the priority specialties and scientific directions of the Chairs of "Engineering" and "Economics" faculties at SSU have been defined:

-intelligible automated information systems;

- corporative information systems;

- automation and management of technological processes;

- development of software applications;

- accounting;

- economics management and management;

-marketing.

Based on the working principles of the specialty, scientific directions and flexible manufacturing areas of the faculties of "Engineering" and "Economics" of SSU, a complex functional scheme of learning training production research - production - commercial system is offered (figure. 1).

Due to the proposed functional scheme of learning training - scientific research production - commercial system, issues of certification, conducting of scientific research and production of innovative projects, studying the fundamentals of economics and business organization should be implemented. In this regard, laboratories of chairs of 
"Engineering" and "Economics" faculties, their visual technical, software and methodical resources and proposed new learning training - scientific research-production-commersial system (TLSRPCS) is processed (figure.1).

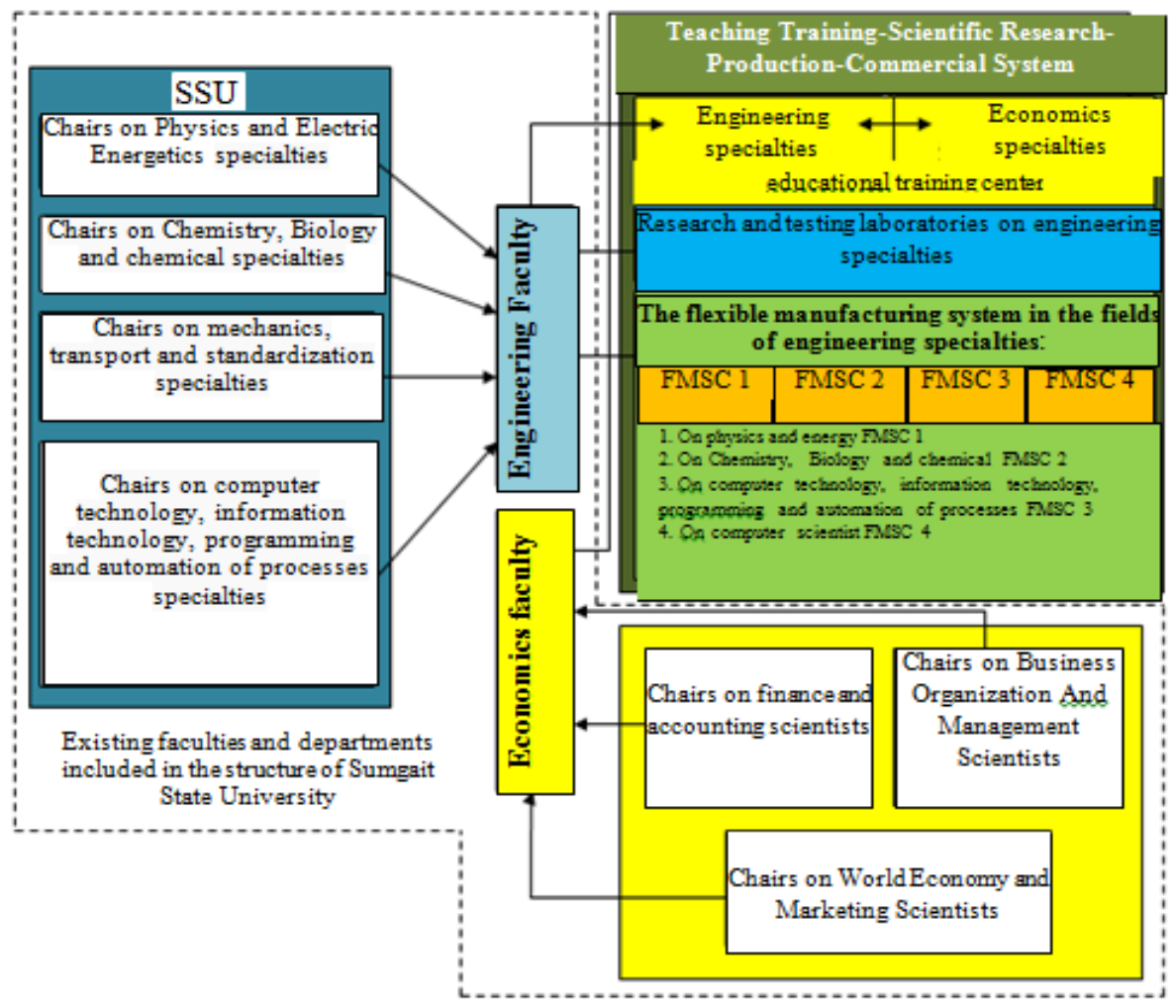

Figure 1. Functional scheme of teaching learning-scientific research-production-commercial system at SSU.

Source: Own performance

The training center of TLSRPCS has a three-level architectural structure. Teaching training departments for the specialities of power engineering, standardization, programming, automation of processes and economics are replaced in the sub - level. The teaching-learning center, which carries out the qualifications for students studying at SSU consists of equipment, machine tools, devices, manipulators, measuring instruments, multimedia tools, automated work places and other teaching and learning tools. Includes informational, methodological teaching aids that provide a mid-level learning process. A technical library functions to provide theoretical and practical lessons on each specialty section. In order to improve the quality of teaching learning process at this level center's social network, educational programs of each department, exam questions, test templates, and specialized electronic libraries are planned. 
An upstream level assessment and certification department of educational training center organizes an official exam that provides students to master theoretical and practical knowledge in learning process. Practical knowledge is checked in written and oral form by the specialists and evaluated by 100-point system with the help of a special template. Theoretical knowledge is checked by an electronic assessment system prepared in accordance with the qualifications test. Students who successfully passed the test are given a certificate that allow them to work in production.

One of the main tasks of TLSRPCS is to explore the process of developing innovative projects in the training center by theoretical methods in engineering and economics departments and initially conduct practical work. However, the solution of the issues on the development of new project is implemented in scientific research and testing laboratories in engineering and economics.

Research and testing laboratories of SSU's TLSRPCS in engineering specialties are equipped with modern automated work places, specialized visual equipment, measuring instruments, multimedia equipment, local and global computer networks. The innovative project selected by the experts is designed virtually in research laboratory, checked by computer experiments, worker model is prepared and after testing the product is manufactured according to the international quality standards in a flexible production area (FMC). Exemplary composes scheme of qualified mechanics of FMC included in flexible production system is shown on figure 2 .

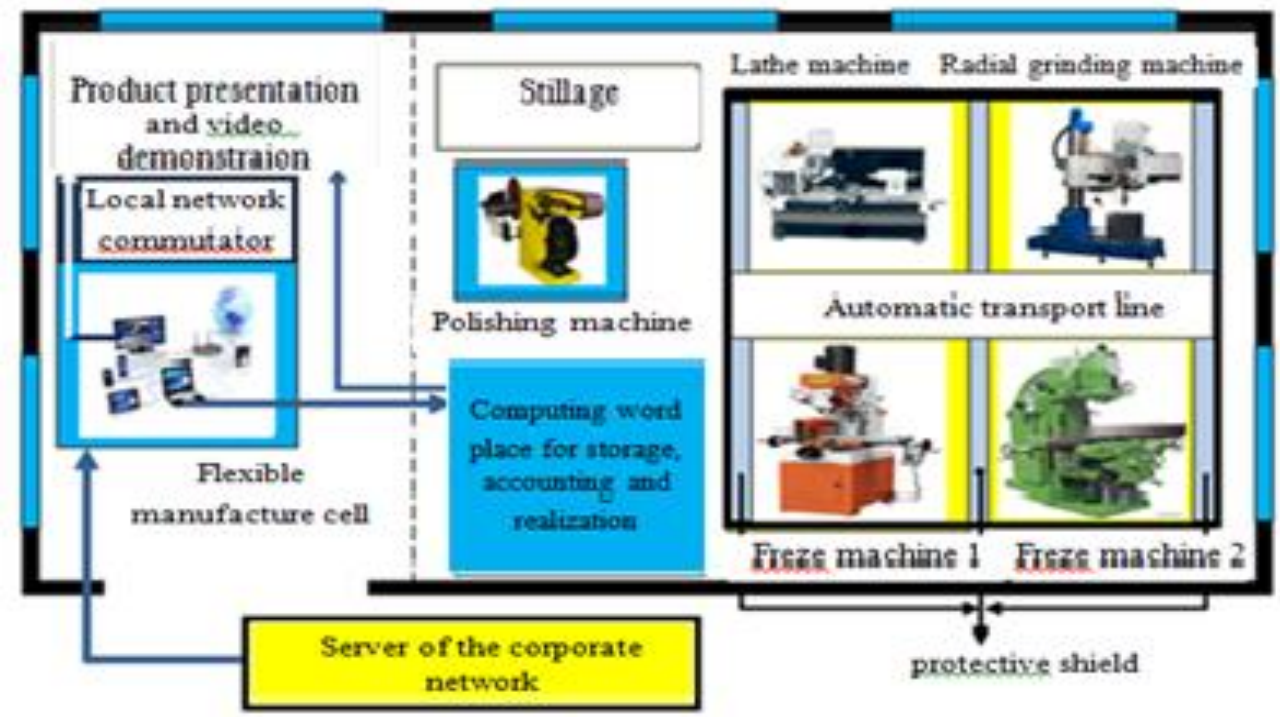

Figure 2. Composes scheme of FMC consisting of mechanical machine tools. Source: Own performance 
- managing body. The task of this organization is to design and build TLSRPCS objects in the field of high technology [Faraco R. A.];

- expert council performing expert evaluation and selection of projects. It includes experts of research and testing laboratories in engineering and economics, managers of FAC, expert professionals, and specialists of funds providing development of enterprises in scientific and technical.

The following stimulus issues should be used to support the development of various business processes at TLSRPCS (Kirchberger A.):

- "tax reform" - favorable tax and administrative conditions allow for free development of teaching, scientific research and production commercialization;

- separate commerce issues (finance, accounting, and leasing, marketing, management) of teaching, researching and flexible production areas should be provide with the help of economics section.

- supplementary wage (based on labor contract) of teachers working at the expense of payments by students or trainees who receives second-year specialization in economic education training should be provided;

-students who receive second-year specialization in teaching and learning department should have preferential payments (50\% lower) than those of the trainees;

- provision of favorable rental of workplaces (use of technological equipment and devices, equipment, automated workplace, local and global computer network) in research laboratories and production should be provided to the student and teachers working on innovative projects;

-a free economic zone should be provided for the winners of the startup projects organized in TLSRPCS. Small businesses are given opportinuty to operate profitably.

-provision of favorable rental of workplaces for the development of projects "Scientists of tomorrow"in TLSRPCS's scientific-research and flexible manufacturing cell.

The following activities should be carried out at the stages to provide comprehensive training, research and production activities in TLSRPCS of SSU [Mamedov J.F.]:

Stage 1. TLSRPCS's architects, designer designs documentations are prepared and approved;

Stage 2. TLSRPCS's engineering and economic oriented training center, research and testing laboratories are built and repaired in accordance with modern construction requirements and are provided with main equipments; 
Stage 3. Flexible manufacturing cell of TLSRPCS are constructed in accordance with construction and security requirements and maintained;

Stage 4. Designing and building of engineer network, social infrastructure facilities are provided.

Stage 5. TLSRPCS's corporate information system is being created, implemented and checked.

TLSRPCS is created as a joint enterprise to ensure mutual relations with SSU and State Research Centers. SSU concludes contracts with executives of scientific innovation projects. Systematic monitoring of the innovative projects prepared by TLSRPCS is ensured and their commercials are provided. A database management system is being developed for research, scientific potentials, specialties, visual aids, electronic libraries, scientific publishing (local and international) and research opportunities for engineering and economics departments of SSU to carry out mutually beneficial research and development between Scientific-research and FMC. Additionally TLSRPCS provide business planning, marketing, and financing for business of FMC .

\section{Expected results}

1. Qualified students have the opportunity to acquire new specialties at TLSRPCS established on the basis of engineering and economics faculties of higher education schools. Professors - teachers and young researchers may have the opportunity to master business, financial management and other issues of economy along with their speciality.

2. Professor -teachers and young researchers at scientific-research laboratories established on the basis of the Faculty of Engineering at the Higher Education School can have the opportunity to carry out and implement their own research work.

3. There may be opportinuty of certification, patenting and exhibiting of innovative projects.International patenting and certification of new innovative projects developed by professors - teachers and young researchers can be achieved.

\section{Conclusion}

1. A functional scheme of the training - scientific- research - production - commercial system which provides training, certification, scientific research and production of innovative projects, studying the basics of economy and business organization in higher education institution has been proposed. 
2. A Composes scheme of flexible manufacturing system for preparation of innovative projects in applied mechanics and machinery parts has been proposed.

3. Stages of complex activity of training, teaching, scientific research and production areas in higher education institution has been proposed.

\section{References}

Dezilacruz, M. D., Fregonezi, G.A. (2015) Science and Technology Parks: Laboratories of innovation for urban development - an approach from Brazil. Journal of UniversityIndustry-Government Innovation and Entrepreneurship, DOI: 10.1186/s40604-0150018-1, 22 p.

Faraco, R. A., Mussi, C., Angeloni, M.T. (2014) Social Networks and KnowledgeTransfer in Technological Park Companies in Brazil. Journal of Technology Management and Innovation, Vol. 9, № 2, p. 172-185.

Kirchberger, A., Larissa, P. (2016) Technology commercialization: a literature review of success factors and antecedents across different contexts. Journal of Technology Transfer., Volume 41, Issue 5, pp. 1077-1112.

Lamperti, F., Mavilia, R., Castellini, S. (2015) The role of Science Parks: a puzzle of growth, innovation and R\&D investments // The Journal of Technology Transfer, DOI 10.1007/s10961- 015-9455-2.

Mamedov, J. F. (2011) Organization of Technology Park and its structure at high educational school of Azerbaijan. European researcher, № 10 (13). p. 1370-1375.

Prencipe, A. (2016). Board Composition and Innovation in University Spin-offs. Evidence from the Italian Context. Journal of Technology Management and Innovation. Vol 11, № 3 , pp. 3 